УДК 94(477:=162.1)“1953/1985”

\author{
Yuliia KSHANOVSKA \\ PhD student of the I. Krypiakevych Institute \\ of Ukrainian Studies of the National Academy \\ of Sciences of Ukraine \\ ORCID 0000-0002-2535-998X \\ yulliakshanovska@gmail.com \\ DOI: 10.33402/up.2018-11-122-130
}

\title{
POLISH COMMUNITY IN THE DAILY PRACTICE OF SOVIET CITIES: INTEGRATION STRATEGIES AND IDENTITY PRESERVATION (ON THE EXAMPLE OF THE DNIPROPETROVSK REGION 1953-1985)
}

The Polish community in the Dnipropetrovsk region has a long history, however, and little studied in comparison with other regions of Ukraine. Poles who migrated to the Eastern Territories of Ukraine are mostly large land magnates, engineering and technical personnel, and ordinary workers, and after the Second World War - Poles who were victims of forced relocations, or entered military service.

The Polish community that was formed in 1953 was heterogeneous, and was completely transformed. Getting into the cities and villages of the Dnipropetrovsk region, the Poles were quickly assimilation, and experienced total Russification (in the villages mostly Ukrainization). The Soviet government has done everything possible to close the Polish community access to churches that have been closed since 1948, and handed over to the use of city councils. However, rarely, but still partially, the Poles managed to instill their customs or culture in local residents, which certainly influenced their self-awareness and lifestyle changes.

The cities where the Poles lived most of all became Russian, and filled the city space with newly arrived Russians to control the party apparatus on the ground, and ensure the formation of the «Soviet Self» in the minds of the local population. The Poles who lived here were the first to undergo the policies of this system - not a single newspaper, school, circle or television was in Polish (before the war the Polish-language school was functioning) - which was the first reasons for the gradual assimilation of the Polish community.

The Poles who lived in the villages - adapted to local life, most of them became «relatives» according to the memories of the residents, and the rest, if possible, traveled to Poland, or to the nearest cities.

Keywords: Poles, Dnipropetrovsk, Dneprodzerzhinsk, Kamianske, demographic changes, population census, assimilation.

The Polish community in the Dnipropetrovsk region occupies a rather important place in the history of the region. In contrast to the history of Western Ukraine, the 
Southern and Eastern regions were settled exclusively by Poles migrants who were sent to work in Ukraine, partially deported from the Eastern territories of Poland, military, or deported deeply to Eastern Russia, who managed to return as close as possible to «civilization». In general, the study is based on the materials of memories of the long-assimilated Poles, as well as on materials of the Soviet censuses. Unfortunately, there is not a single study that reveals the history of the Polish community in the Dnipropetrovsk region.

Even before the war in the Dnipropetrovsk region there were several regions in which the Poles lived. This is Dnipropetrovsk (Katerynoslav) - mainly the left-bank part of the city and its surroundings, Novomoskovsk - the district center near Dnipropetrovsk, Kryvyi Rih, Pavlograd, Nikopol and Kamianske (Dniprodzerzhynsk - one of the largest centers of the Polish population of the region) ${ }^{1}$. «...Samoilenko K. P. (Shtukalska) - Who are you by nationality? - Ukrainian. - What is your education? - I went to school only three years. - Where did you work? - I do not remember the period of German occupation, I was small. When the occupation ended, we assisted our parents in the field. Only women and the elderly remained after the war. They sowed fields, we helped with rakes. When the war ended, I worked on a farm, looking after calves. Then I worked as a milkmaid, and later on various jobs. - What was your parent's name? - My father is Shtukalsky Petro, his parents were Poles. My mother was Ukrainian, her name was Shevchenko Harytyna, she was from the Poltava region... - And my dad's parents were from the Krakow Voivodeship, my great-grandmother used to say that, saying that they were rich. They came here to buy land. They stayed here and died here... $\rangle^{2}$. This accurately describes the fate of the Poles who moved to Eastern Ukraine in search of a better life.

According to the census of 1897, 12,365 people considered Polish as their mother tongue in Katerynoslav Province: in Katerynoslav this share was $3.3 \%$ (6686 people) of the total population of the city, in Novomoskovsk $-0.5 \%$ (76 people), in Pavlograd $-2 \%$ (312 people), in Kamianske - $16.2 \%$ (2736 people) $)^{3}$. On the other hand, in Kamianske formed national city space artificially - by building a metallurgical plant here, which was moved from Warsaw. The rest of the cities and towns were filled naturally by the Polish minority from the second half of the 19th century, when the majority of Polish landowners bought land in the south of Ukraine. After the end of the forced relocation, the socio-professional structure of the Poles in Dnipropetrovsk region changed significantly. In the cities there were farmers, unskilled engineers, and ordinary workers. The Polish community had to develop its own culture and teach Polish children: «The situation was similar to the period of interwar life, with only one difference - the Poles were not allowed into leadership positions ${ }^{4}$.

After repression and forced exchanges of population for the Poles of Dnipropetrovsk, a period begins, which are mainly called the period of the Soviet «hidden» existence

1 Фоменко А. Дніпропетровськ: минуле і сучасне. Дніпропетровськ. 2001. С. 61.

2 Інтерв’ю з Самойленко К. П., 1931 р. н., записане у місті Кривий Ріг 22 липня 2018 р. Архів автора.

3 Державний архів Дніпропетровської області (далі - Держархів Дніпропетровської обл.). Ф. 416. Оп. 1. Спр. 82. Ар. 1-13.

4 Інтерв’ю з Лісовською О. К., 1939 р. н., записане у місті Дніпро 13 липня 2018 р. Архів автора. 
of the Polish community ${ }^{5}$. After Stalin's death, the majority of the population, including the Poles, hoped for a partial easing of the party's policy on the existence of national minorities on the territory of the USSR; however, already after the first decrees of the new leadership, the hopes were not fulfilled. Beginning in the second half of the 1950s, two branches of Poles could be distinguished in Dnipropetrovsk: 1) Poles who did not manage to leave the region were massively assimilated, thereby avoiding unnecessary questions to themselves and their family, 2) and those that continued to be called themselves Poles are mostly «newly arrived specialists» from Poland, who were invited to work in the Union under a contract. It was from these two groups that the Polish community of Dnipropetrovsk consisted. In fact, such a distribution influenced their self-identification, their way of life, and, in general, the separation of their «myself» in the Soviet society.

One of the largest centers of life of the Polish community in the Dnipropetrovsk region was Kamianske (Dniprodzerzhinsk). According to the city census of 1913, 14,175 Poles lived in the city, which accounted for $57.9 \%$ of the total city ${ }^{6}$. This was due to the fact that at the end of the 19th century the Warsaw Construction Plant transferred its equipment to Kamianske, where the city's system developed and filled with workers of Polish nationality, sent from Warsaw? ${ }^{7}$ Later, however, a «city in the city» appeared in the city: the Soviet government began the mass construction of a new working district in Dniprodzerzhinsk, and already in the 1960s-1970s, a new town began to grow around the Upper Colony (the former working settlement where mainly Poles lived - workers of the Metallurgical Plant) - Sotsgorod (built exclusively in the Soviet style, the city quickly absorbed the Gothic and classical architecture of Polish houses). The new Soviet city became the face of Kamianske, but the Upper Colony slowly began to collapse (although this did not prevent today being this part of the district and being called the Old Town).

In Dnipropetrovsk, the situation was similar. The majority of the Polish population were workers of the largest factories in the region, so it was often the case that the workers who were sent here by contract took their families with them, and created favorable conditions for their life. In contrast to Dniprodzerzhinsk, in Dnipropetrovsk the Poles failed to become one of the leading national groups of the city. Here, the city's population has always been divided between three nations: Ukrainians, Jews, Russians, but according to the 1917 census, 14,959 people of Polish nationality lived in Katerynoslav, which accounted for $6.9 \%$ of the total population of the city ${ }^{8}$. In 1926, this figure was already 5823 people $-2.5 \%$ of the total population of the city ${ }^{9}$.

5 Афанасьєв О. Є. Історико-географічна спадщина польського народу на території південно-східної України. Культура народов Причерноморья. 2011. № 200. С. 80.

${ }^{6}$ Сабов М. М. Особливості формування робітничого поселення на території с. Кам'янське в період індустріалізації Придніпров'я наприкінці XX - початку XX століть: малодосліджені аспекти соціальних відносин. Придніпров'я: зб. наук. праць. Дніпропетровськ, 2012. Вип. 10. С. 37.

7 Фоменко А. Дніпропетровськ: минуле і сучасне. Дніпропетровськ. 2001. С. 62.

8 Катеринославська міська статистика. 1918. Вип. 1. С. 7; Держархів Дніпропетровської обл. Ф. 416. Оп. 1. Спр. 82. Арк. 14; Міські селища УРСР. Збірник статистично-економічних відомостей. Харків, 1929. С. 4-23.

9 Україна. Статистичний щзорічник ЦСУ УСРР 1926-1929. Харків, 1929. Табл. 6. С. 13. 
The rest of the cities - such as Kryvyi Rih, Pavlograd, Novomoskovsk and Nikopol had a small presence here of the Polish population, the figure ranged from $1.6 \%$ to $2.2 \%$ of the total population ${ }^{10}$. However, the situation in these regions was interesting because $60.6 \%$ of Poles lived in villages, and not in cities. But such a factor caused even greater assimilation of national minorities. After all, if in the city it was possible to get at least some access to information, or to communicate with each other, while in the village Polish families were isolated cases, and the only thing left for them was assimilation, but Ukrainian-speaking, not Russian-speaking - how it is was inherent for cities: «Did many people who came from the city stay in the village forever? - Yes, many. The big families stayed here, the Shram's family from western Ukraine, they came from Poland. - Did they quickly become «native»? We are all the people. We had twelve nationalities in our village: Germans, Jews, Russians, Ukrainians, Tatars. But we have always been friendly, no matter who you are? I also know, a long time ago, when there were no collective farms, there were years when people went to our village to exchange food, take our vegetables. This was probably before the revolution» ${ }^{11}$.

The greatest symbol of the Polish community of cities, of course, were religious shrines. At the time of 1953-1986. in the area there were only three. Even before the end of the war and in the early postwar years, the churches in Dnipropetrovsk and Dniprodzerzhinsk were forbidden, but could function in one way or another. In 1948, the city government took away from the Polish community Catholic church of sv. Joseph in Dnipropetrovsk, and signed a decree on the establishment of a public library there ${ }^{12}$. Subsequently, the church was reconstructed, virtually unrecognizable, and in 1950 opened the School of higher sportsmanship there. Back in the early 1950s, the Catholics of the city tried to prevent it and wrote letters and appeals to the city executive committee with requests to return the building. Church of sv. Nicholas in Dniprodzerzhinsk was closed in 1929, where from time to time various cultural and nomenclature organizations were located there. There was also the Church of the Assumption of the Blessed Virgin Mary in Yamburg (German colony in the village of Dniprove), closed in 1948 and destroyed by order of the regional executive committee in $1986^{13}$. There was no help with the PPR for the Polish population, who had USSR citizenship. At that time there was a modest network of diplomatic and consular missions in the Soviet Union (Moscow, Minsk, Kyiv, Leningrad), and the Soviet authorities completely refused to engage in the life of the Polish communities of the USSR, justifying this with constitutional guarantees of civil rights for all, without using ethnic criteria. Another important sign was that Dnipropetrovsk and Dniprodzerzhinsk were cities of the «closed space», in connection with the deployment of space rockets ${ }^{14}$. Because of its secrecy, the city, although not

\footnotetext{
${ }^{10}$ Всесоюзная перепись населения 1926 года. Национальный состав населения по республикам CCCP. URL: http://demoscope.ru/weekly/ssp/ussr_nac_26.php?reg=4

${ }^{11}$ Інтерв'ю з Олійник Ю. І., 1937 р. н., записане у місті Павлоград 15 липня 2018 р. Архів автора.

12 Фоменко А. Дніпропетровськ: минуле і сучасне. Дніпропетровськ, 2001. С. 62.

${ }^{13}$ Ibid

${ }^{14}$ Портнова Т. Тема «закритого міста» в історії радянського Дніпропетровська 19501980-х pp. Historians. 11 грудня 2017. URL: http:/www.historians.in.ua/index.php/en/
} 
officially, was considered closed to foreign citizens, and all migration movements were firmly controlled by the KGB.

After the closure of religious institutions began total assimilation of the population. The lack of Polish-language schools, access to the church - there is a loss of language and ethnic identity. All censuses since 1926 show a permanent decrease in the number of Poles in the Dnipropetrovsk region ${ }^{15}$. But it should be noted that the Polish language was not always a national sign, in fact, just like the Catholic religion. Before and after the war, in the region from $1 \%$ to $2.5 \%$ of Poles lived, this figure gradually decreased ${ }^{16}$. Usually such a situation was caused by war, repression and forced relocations, however, the fact that the majority of families had mixed marriages between the 70s and $80 \mathrm{~s}$ and communicated mainly in Russian-Ukrainian is not to be denied ${ }^{17}$. In 1970, 6686 people of Polish nationality lived in the Dnipropetrovsk region $(0.2 \%$ of the total population of the region), however, the population of the cities grew, and national minorities lost their presence in the urban environment, and as of 1979 were 5458 people lived in this region $(0.15 \% \text { of total population of the region })^{18}$.

In the conditions of the new for the Poles of the Soviet society at the turn of the 50-60s, it was impossible to get used to everyday life. After all, the majority (Poles that came to the Dnipropetrovsk region to work under a contract) faced this problem for the first time - in the cities total Russification: «...even for us - Poles, who have lived here for 20 years, it was difficult to get used to a new way of life. Our newspaper was taken away, there were two Polish schools in the city - they took it away, the Russian language was everywhere; in the school where my children studied - there was not even the Ukrainian language, and all our efforts to somehow preserve our culture were unsuccessful.» ${ }^{19}$. Looking through the press of the Dnipropetrovsk region, can really pay attention to one important point. Regional publications were printed in two languages - Ukrainian and Russian, «Whoever wants, then choose» (Could hear in most interviews, to the question «Which press did you prefer?»)*, but even looking through the Russian-language and

doslidzhennya/2351-tetyana-portnova-tema-zakritogo-mista-v-istoriji-radyanskogo-dnipropetrovska-1950-80-kh-rokiv

15 Україна. Статистичний щзорічник ЦСУ УСРР 1926-1929. С. 34.

${ }^{16}$ Всесоюзная перепись населения 1939 года. Основные итоги. Москва: Наука, 1992. Таб. 8. С. 64; Итоги Всесоюзной переписи населения 1959 года: Украинской ССР. Москва, 1963. С. 18, 24.

${ }^{17}$ Kulischer E. M. Europe on the move. War and population changes 1917-47. New-York: Columbia University Press. 1948. P. 12-13; Национальный состав населения Днепропетровской области. Статистический сборник. Днепропетровск, 1991. С. 8.

${ }^{18}$ Ibid.

${ }^{19}$ Інтерв'ю з Гужевським С. О., 1954 р. н., записане у місті Кам'янське 11 липня 2018 р. Архів автора.

* The conclusions were made on the basis of all interviews collected in the Dnipropetrovsk region as of July 2018. The age of the respondents ranged from 51 to 85 years. Most of the respondents answered unanimously, some (respondents from cities, mostly to the East and South from the Dnipro, stated that they read the Russian-language newspaper, and only residents of villages and the city of Kamianske answered that they preferred the Ukrainian-language press, 
Ukrainian-language newspapers of the same publication, it was possible to find differences in articles, and indeed in the topics of publications. But the popular city press was issued exclusively in Russian, and the newspaper of Dnipropetrovsk «Dnipro vechirnii», which resumed its release after the war only in 1970, issued the first three quarters of the circulation in Ukrainian, the rest in Russian.

In the cities, it was easier for the newly arrived Poles to preserve their culture and identity. Polish language in public space was limited to private conversations and inscriptions on tombstones in Catholic cemeteries.

The majority of Polish families who came to the Dnipropetrovsk region were familiar with each other, and from time to time they communicated, maintaining friendly relations: "If honestly, in Poland, too, the communists did not particularly perceive the celebration of Christmas or Easter, but still, history cannot be eradicated to the end. After arriving in the Dnipropetrovsk was very difficult. Most likely was difficult to adapt to the city space, to citizens... But we were gathering together for the holidays, and were supporting our former way of life...but then many of them left the Dnipro...mostly went to Lithuania. At first they wrote letters to us, but later they stopped writing, one of them died, and someone went to another place, so everything died down .... ${ }^{20}$.

The Poles who were invited to work in the region lived in houses for engineers mostly two- or three-story houses with apartments for several families. It was difficult to adapt to life for women and children. At first, women were at home and engaged in upbringing, but later most went to work in hospitals, kindergartens and schools. The adaptation of children was also difficult, people had to hire teachers so that children could learn Russian and communicate freely in school: "...we arrived in Dnepropetrovsk in 1958, my husband was sent to work in the Rocket Factory, I stayed permanently at home, there was no work for me, besides who would hire me without a language. It was a little creepy to live here, it was a constant control. All of this because my husband worked at the rocket plant. I was bored, so I decided to get a night job at kindergarten. When my daughter was born, I had to stay home again, so I decided to learn the local language. My neighbor was Ukrainian, she and her family came here from the Ternopil region, she knew Polish, and from her I learned to speak Ukrainian, but my children speak Russian. My husband was an engineer at the factory, so we had no problems with money, we decided to send our children to study in a Russian-language school, we were told that Russian-language schools are better and the prospects are greater...» ${ }^{21}$.

The only link of the PPR an Dnipropetrovsk region was the press. On the pages of the newspaper «Zoria» (regional newspaper) and «Dnipro vechirnii» (Dnipropetrovsk city newspaper) there was always a column «Planet. To lead News. Events.», some of them were dedicated specifically to Poland. Inna Barvinok was the editor-in-chief of the column «Letters to friends to Poland», she traveled to Poland several times. A definite

\footnotetext{
${ }^{i t}$ was more convenient, since basically everything was the village spoke Ukrainian, so reading Ukrainian was much easier).

${ }^{20}$ Інтерв'ю з Гужевською О. М., 1942 р. н., записане у місті Кам’янське 11 липня 2018 р. Архів автора.

${ }^{21}$ Інтерв’ю з Квасневською А. І., 1944 р. н., записане у місті Дніпро 24 липня 2018 р. Архів автора.
} 
novelty in the activities of the Polish community of Dnipropetrovsk was trips to Poland, on the basis of an agreement on cultural cooperation and networking with communities and educational institutions*. During these visits, Poles from Dnipropetrovsk region participated in trainings and meetings, visited and learned about their historic homeland. About these and other events are always told on the pages of the Dnipropetrovsk press, both urban and regional newspapers.

So, despite the constant prohibition total national and Sovietization policies, Polish culture brought to the territory of Dnipropetrovsk region under the nomenklatura regime could exist. Mass prohibition and total propaganda, the plantings of the Soviet way of life did not prevent the Poles from developing themselves. However, the changes brought about by the new Soviet system after the war undoubtedly influenced the way of life of the local people, in particular the Poles. After the overthrow of the Soviet regime, the Polish community began a gradual restoration of its activities in the region, and also contributed to the discovery of other cells of Polish culture in the Dnipropetrovsk region. Although today the majority of Polish residents consider themselves already indigenous to the city, but they constantly emphasize their nationality - the Poles.

\section{REFERENCES}

Afanasiev, O. Y. (2011). Istoryko-heohrafichna spadshchyna polskoho narodu na terytorii pivdenno-skhidnoi Ukrainy. Kultura narodov Prychernomoria. (200). 78-82 [in Ukrainian].

Fomenko, A. (2001). Dnipropetrovsk: mynule i suchasne. Dnipropetrovsk. Dniproknyha [in Ukrainian].

Huzhevska, O. M. (Personal communication, July 11, 2018). [in Ukrainian]. Interview by Y. M. Kshanovska [In-person].

Huzhevskyi, S. O. (Personal communication, July 11, 2018). [in Ukrainian]. Interview by Y. M. Kshanovska [In-person].

Itogi Vsesoyuznoy perepisi naseleniya 1959 goda: Ukrainskoy SSR. (1963). Moskva: Gosstatizdat [in Russian].

Katerynoslavska miska statystyka. (1918). Katerynoslav, (1), 1-9 [in Ukrainian].

Kulischer, E. M. (1948). Europe on the move. War and population changes 1917-47. New-York. Columbia University Press. 12-13 [in English].

Kvasnevska, A. I. (Personal communication, July 24, 2018). [in Ukrainian]. Interview by Y. M. Kshanovska [In-person].

Lisovska, O. K. (Personal communication, July 13, 2018) [in Ukrainian]. Interview by Y. M. Kshanovska [In-person].

Miski selyshcha URSR. Zbirnyk statystychno-ekonomichnykh vidomostei. (1929). Kharkiv: TsSU USRR. 4-23 [in Ukrainian].

* The conclusion was made on the basis of the analysis of the press «Zorya» and «Dnipro Vechirny» (regional and city newspaper), each issue of which contained a separate column «Letters of Friends from Poland» and «World Events», mainly devoted to cooperation between the Union republics, new arrangements, general discoveries ets. 
Natsional'nyy sostav naseleniya Dnepropetrovskoy oblasti. Statisticheskiy sbornik. (1991). Dnepropetrovsk [in Ukrainian].

Oliinyk, Y. I. (Personal communication, July 15, 2018). [in Ukrainian]. Interview by Y. M. Kshanovska [In-person].

Portnova, T. (2017). Tema zakrytoho mista v istorii radianskoho Dnipropetrovska 1950-1980rr. Retrieved from http://www.historians.in.ua/index.php/en/ doslidzhennya/2351-tetyana-portnova-tema-zakritogo-mista-v-istoriji-radyanskogodnipropetrovska-1950-80-kh-rokiv [in Ukrainian].

Sabov, M. M. (2012). Osoblyvosti formuvannia robitnychoho poselennia na terytorii s. Kamianske v period industrializatsii Prydniprovia naprykintsi XIX - pochatku XX stolit: malodoslidzheni aspekty sotsialnykh vidnosyn. Prydniprovia: zbirnyk naukovykh prats, 10, 34-41 [in Ukrainian].

Samoilenko, K. P. (Personal communication, July 22, 2018). [in Ukrainian]. Interview by Y. M. Kshanovska [In-person].

Ukraina. Statystychnyi shchorichnyk 1926-1929. (1929). Kharkiv: TsSU USRR [in Ukrainian].

Vsesoyuznaya perepis naseleniya 1926 goda. Natsionalnyy sostav naseleniya po respublikam SSSR Retrieved from http://demoscope.ru/weekly/ssp/ussr_nac_26. php?reg=4 [in Russian].

Vsesoyuznaya perepis' naseleniya 1939 goda. Osnovnyye itogi. (1992). Moskva: Nauka [in Russian].

Юлія Кшановська. Польська спільнота у повсякденних практиках радянських міст: стратегії інтеграції та збереження ідентичності (на прикладі Дніпропетровської області 1953-1985 рр.)

Польська спільнота на Дніпропетровщині має багатовікову історію, проте і досліджену чи не найменше 3-поміж інших регіонів України. Поляки, які переселялися на східні терени України, - це здебільшого великі земельні магнати, підприємці, інженерно-технічні кадри та заробітчани, а після Другої світової війни - поляки, які стали жертвами примусових переселень, та ті, які отримали роботу за контрактом або ж вступили на військову службу.

Прошарок польської спільноти, що сформувався станом на 1953 р., був неоднорідний та зазнав цілковитої трансформації. Потрапляючи як до міст, так і до сіл Дніпропетровщини, поляки швидко асимільовувалися, але зазнавали тотальної русифікації (у селах переважно українізовувалися). Радянська влада зробила все можливе, аби закрити польській громаді доступ до основного - костелів, які були зачинені ще з 1948 р. та передані в користування міських рад задля «кращого призначення». Дуже рідко, та все ж полякам вдавалося прищепити свої звичаї чи культуру тамтешнім жителям, що неодмінно впливало на їхню самосвідомість та зміну способу життя.

Міста, у яких проживало найбільше поляків, ставали зросійщеними і наповнювали міський простір новоприбулими росіянами задля керування партійним апаратом на місцях та забезпечення формування «радянського Я» у свідомості місцевого населення. Поляки, які тут мешкали, - першими зазнали політики цієї системи - жодної газети, школи, гуртка чи телебачення польською мовою не було 
(до війни у Дніпродзержинську функціонувала польськомовна школа), що й стало першою причиною поступової асиміляції польської спільноти.

Поляки, які проживали у селах, - українізовувалися та пристосовувалися до тамтешнього життя, більшість 3 них ставала «своїми», згідно зі спогадами мешканців, решта - за можливості виїздили до Польщі або ж до міста.

Ключові слова: поляки, Дніпропетровськ, Дніпродзержинськ, Кам’янське, повсякдення, демографічні зміни, перепис населення, асиміляція.

Julia Kszanowska. Społeczność polska w życiu codzinnym miast radzieckich: strategie integracji i zachowania tożsamości (np. regionu dniepropietrowskiego 1953-1985)

Losy społeczności polskiej w regionie Dniepropietrowskim ma długą historię, ale została dotąd słabo zbadana w porównaniu z innymi regionami Ukrainy. Polacy, którzy przenieśli się na wschodnie tereny Ukrainy przed wiekiem XX-tym, to głównie właściciele ziemscy, przedsiębiorcy, inżynierowie i robotnicy, a po drugiej wojnie światowej byli to Polacy, którzy padli wcześniej ofiarą przymusowych wysiedleń, i ci, którzy dostali pracę najemną, lub wstąpili do służby wojskowej w ZSRR.

Społeczność polska, która powstała w 1953 r., była heterogeniczna i uległa całkowitej transformacji. Dojeżdżając do miast i wsi regionu Dniepropietrowskiego, Polacy szybko zasymilowali się i doświadczyli całkowitej rusyfikacji (w większości wsi następował proces ukrainizacji). Władze radzieckie dołożyły wszelkich starań, aby zamknąć dostęp społeczności polskiej do kościołów, które zamknięto w 1948 r. i przekazano do użytku radom miejskim w celu «lepszego przeznaczenia». Nierzadko, mimo wszystko, Polakom udało się utrwalić, ocalić od zapomnienia, swoje zwyczaje, kulturę, także wśród lokalnych mieszkańców, co nieuchronnie wpłynęło na ich samoświadomość i zmianę stylu życia.

Miasta, w których żyli większości Polacy, zostały zrusyfikowane. Przestrzeń miejską zapełniono nowo przybyłymi Rosjanami, by kontrolować aparat partyjny na prowincji i zapewnić powstanie «sowieckiego Ja» w umysłach miejscowej ludności. Polacy, którzy tu mieszkali - jako pierwsi cierpieli z powodu tak realizowanej polityki - żadna gazeta, szkoła, środowisko czy telewizja nie mogła być polskojęzyczna (szkoła polskojęzyczna funkcjonowała przed wojną w Dnieprodzerzinsku). Była to podstawowa przyczyna stopniowej asymilacji społeczności polskiej w tym regionie.

Polacy mieszkający na wsi - byli ukrainizowani i zmuszani do dostosowania się do sowieckich zasad życia lokalnego. Większość z nich stała się «ich» według wspomnień mieszkańców, reszta - jeśli to możliwe, wyjechała do Polski lub do miasta.

Słowa kluczowe: Polacy, Dniepropietrowsk, Dnieprodzerzinsk, Kamianske, życie codzienne, zmiany demograficzne, spis ludności, asymilacja. 